\title{
An experimental approach to the influence of partial rebar corrosion and concrete degradation on behavior of FRP-strengthened RC beams
}

\author{
M. Abbasi ${ }^{1} \cdot$ H. Naderpour ${ }^{1}$ (I) \\ Received: 21 November 2020 / Accepted: 13 August 2021 \\ Published online: 31 August 2021 \\ (c) The Author(s) 2021 OPEN
}

\begin{abstract}
Human factors are one of the main reasons for structural damage as they decrease the bearing capacity and also lead to an inaccurate estimation of the structure. Previous studies show that the use of CFRP in the damaged structures can significantly increase their bending and shear capacity. This study examines the capacity and cracks distribution in eight RC (reinforced concrete) beams $(210 \times 250 \times 250 \mathrm{~cm})$, each of which was rehabilitated with seven CFRP (carbon fiberreinforced polymer) strips using the strip method. Each beam, except for the control specimen, experiences different types of concrete and rebar damages, which are finally compared with those of the control specimen. The results indicated that rebar damage in all the beams was significant and the effects of concrete damage were minimized by CFRP strips. Moreover, the force-displacement diagrams indicate the greatest force for the control specimen. Other specimens reached up to $80 \%$ of the force experienced by the control specimen. Finally, the parametric study showed that the influence of the crack width on decreasing the bearing capacity was more significant compared with the other parameters.
\end{abstract}

Keywords RC beam · CFRP · Rebar corrosion · Concrete degradation · Composite material

\section{Introduction}

Since the late 1980 s, the rehabilitation method using FRP' has been implemented by a large number of researchers. In comparison with the other rehabilitation techniques, this method has some advantages, including high strength to weight ratio, high resistance against corrosive materials, flexibility, and ductility [1]. Dong et al. compared the ductility of RC beams rehabilitated with FRP composites with those for the other beams [2]. Choi et al. examined the structural and non-cohesive performance of RC beams reinforced with FRP composites [3].

An alternative reinforcing material, fiber-reinforced polymer (FRP) bar, is being considered as a solution to the corrosion problem. Due to their corrosion resistance, FRP bars have received considerable attention, especially from the transportation industry. Applications of FRP bars, however, are not only limited to cases where corrosion is of concern. They are also useful in structures requiring magnetic transparency and in members susceptible to chemical attack [4]. Moreover, in another study, the resistance against flexibility was examined and indicated an increase in the shear capacity of RC beams when strengthened by FRP sheets. In the mentioned method, resistance was more effective than the shear ductility. Another study investigated the discontinuity of FRP on all surfaces because of the cracks and their spread in the damage state [5].

When a structural element is vulnerable to such effects, the fastest and most cost-effective way to prevent damage is to strengthen the element. In the past, the typical methods of shear strengthening of vulnerable RC members involved adding extra RC or steel elements. The

\footnotetext{
1 Fiber-reinforced polymer.
}

H. Naderpour, naderpour@semnan.ac.ir | 'Faculty of Civil Engineering, Semnan University, Semnan 3513119111, Iran. 
traditional methods most commonly used to increase the shear capacity of RC members are (a) adding reinforcement around the cross section and placing concrete around it (concrete jacket) [6].

From the environmental and economic viewpoints, repairing, reviving, and rehabilitating the existing structures are preferred to their demolishing and rebuilding. Furthermore, rehabilitation projects are implemented faster than new projects. Moreover, the new projects put such structures out of operation [7-9] examined the effect of parameters such as the preparation of a concrete surface, cohesive material, and concrete strength on adherence strength and found out that preparing the concrete surface would increase the adherence strength by $3-11 \%$ [10].

Many different fractures of $\mathrm{RC}$ beams reinforced with FRP sheets have been observed in experimental studies. These fractures are highly diverse, as some researchers have reported more than 30 different fracture cases. According to the previous studies, different kinds of bending damage in rehabilitated specimens are (1) yielding of longitudinal bars along with the fracture of fiber polymers; (2) concrete crushing under compression before the fracture of fiber polymers; (3) separation of the polymer fiber ends from the concrete surface along with the concrete cover of longitudinal rebars; (4) separation of the polymer fiber ends from the concrete surface, and a part of the concrete cover (a rare case); (5) separation of the polymer fiber ends from the concrete surface and a part of the concrete cover because of bending cracks; and (6) separation of polymer fiber ends from the concrete surface and a part of the concrete cover because of bending-shear cracks. According to the experimental studies, the cases 4-6 are more observed in beams without transverse reinforcements [11].

In this regard, Kotynia and Cholostiakow exploited the advantages of these two methods and tested nine full-scale beam specimens [12]. They presented a new method, which resulted in higher stiffness and bearing capacity and significantly decreased the beam deflection in the middle of the span. Almusallam et al. examined 11 bending beams $(225 \times 200 \times 150 \mathrm{~mm})$ and analyzed them using the FEM. ${ }^{2}$ They concluded that increasing the tension rebar percentage in non-reinforced beams decreases the ductility of the deflections, as well as the effects of FRP sheets on increasing bending capacity [13].

The type of rehabilitation with FRP to repair the concrete structures depends on the geometrical and mechanical properties of the system. U-type reinforcements, longitudinal elements, FRP straps, and FRP strips are some conventional rehabilitation methods using FRP which have been utilized experimentally and numerically by previous researchers $[6,14-23]$.

\footnotetext{
$\overline{2}$ Finite element method.
}

While a structural element is subjected to detrimental factors, the fastest and the most expensive method to stop the damage spread is rehabilitating the structure. In the past, rehabilitation was mostly limited to adding RC or steel elements [24]. The life span of concrete structural elements highly depends on their repair and rehabilitation. Due to the mistakes and recommendations of bylaws, the structures encounter many dangers. Unacceptable physical and chemical conditions or construction errors make the practitioners use the rehabilitation covers to reinforce the fractured ductile elements [25]. The major contribution to FRP composites is its potential to extend service life of existing structures [26]. The failure mode of completely wrapped beams is FRP rupture, which is more favorable compared to the sudden debonding of the FRP laminates of the U-Wrapped beams. In the case where beams cannot be completely wrapped, the U-wrapping scheme is a feasible option. However, for the U-Wrapped beams to reach the same performance of the completely wrapped beams, CFRP laminates should be properly anchored to avoid the brittle debonding $[27,28]$.

The main objective of this study is to truly evaluate the behavior of RC beams having rebar or concrete damage and rehabilitated with CFRP composites. With using concrete beams and bonding CFRP sheets together in strips, the ultimate bending resistance and displacement in the beam were determined. For this purpose, eight RC beams $(2100 \times 250 \times 250 \mathrm{~mm})$ strengthened with CFRP strips were manufactured. Each beam had a specific pre-damage in the rebar and/or concrete. These specimens were subjected to four-point bending, and the results were compared with those of the control specimen in order to evaluate the efficiency of the rehabilitation technique.

\section{Test layout}

\subsection{Test specimens}

In this study, eight full-scale RC beams were manufactured and tested. All the specimens had $2100 \mathrm{~mm}$ length and a square surface $(250 \mathrm{~mm} \times 250 \mathrm{~mm})$. Since the study purpose was to examine the fracture of the beams with internal damage and to detect the crack spread pattern, the specimens were allowed (based on $\mathrm{ACl} 318$ ) to experience bending cracks. Moreover, a control specimen, with no concrete or rebar damage, was utilized to compare the results of the rehabilitated beams. The amount of the used rebar was $1.23 \%$. The size of steel reinforcements was $\$ 10 @ 200 \mathrm{~mm}$. In accordance with the rebar layout, the span to effective depth ratio $(a / d)$ of the beams was equal to 2.65. The specimens were procured and then tested by a hydraulic jack using a four-point loading. The 


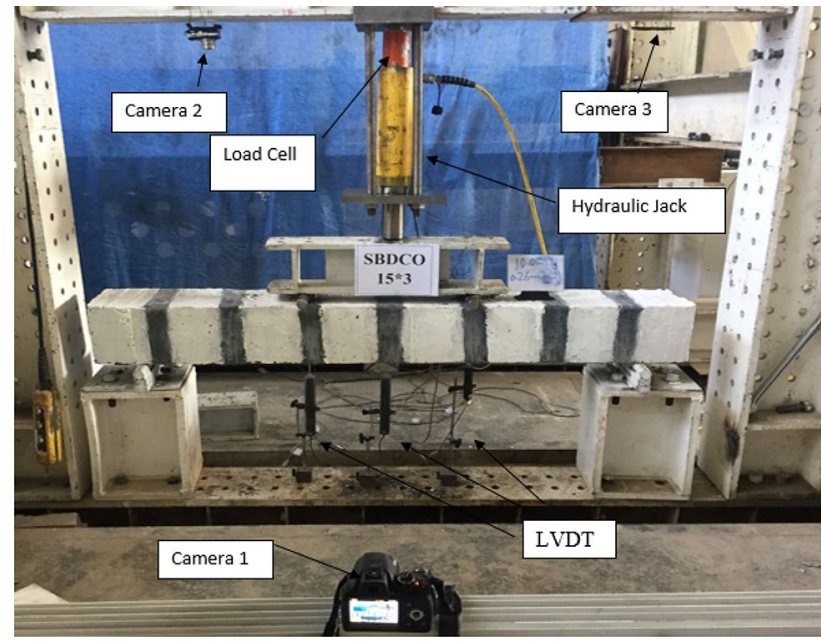

Fig. 1 Details of the test setup and location of cameras and LVDTs

area between the two-point loads had a constant moment and zero shear. In this area, the beam behavior under pure bending could be evaluated. In the area between each load point and the closest support, the combined effect of bending and shear loads can be examined. Static and uniform loads were applied. According to Fig. 1, the middle-point displacement and force can be transferred to the data logger device by $\mathrm{LVDT}^{3}$ and the load cell, respectively. Further, the experimental displacement in the middle of $\mathrm{RC}$ beams reinforced with FRP was determined. Using the load-displacement diagrams from the tests, the beam displacements were determined in different load levels and bearing capacities of the beams reinforced with FRP. Moreover, the observations were recorded in each stage, and the crack spread pattern was illustrated to determine the beam failure mechanism.

The manufactured beams were divided into two categories based on their damage type: beams with concrete damage and beams with rebar damage. Rebar damage includes two $25 \mathrm{~mm}$ corrosions and a decrease in the rebar diameter by half $(7 \mathrm{~mm})$ of the length of the bottom rebars. The beams were reinforced with FRP strips. According to the beam perimeter $(100 \mathrm{~mm})$, some extra strip lengths were considered for the overlaps $(150 \mathrm{~mm})$ in order to maintain the necessary connection and strength. The FRP width is $80 \mathrm{~mm}$, and it is located $200 \mathrm{~mm}$ on either side of the middle point. In the case of concrete damage, special foams with different widths and depths were utilized in order to simulate the damage. All the posed damages are shown in Table 1.

The beams were reinforced with FRP strips. According to the beam perimeter $(100 \mathrm{~mm})$, some extra strip lengths

\footnotetext{
${ }^{3}$ Linear variable displacement transducer.
}

were considered for the overlaps $(150 \mathrm{~mm})$ in order to maintain the necessary connection and strength. The FRP width is $80 \mathrm{~mm}$, and it is located $200 \mathrm{~mm}$ on either side of the middle point. According to Fig. 2, seven FRP strips are installed on each beam. One failure in BDRA samples and two failures in BDRS samples were located in one-third of the effective span of the fixed-end beam with a distance of $60 \mathrm{~cm}$ from the two head supports. It is machined accurately and evenly using a turning tool such that to cause failure. The reinforcement's diameter is reduced from 14 to $7 \mathrm{~mm}$ (Fig. 3).

\subsection{Material properties}

According to the compressive strength tests conducted on the cubic specimens of the concrete used for the beams (with $150 \mathrm{~mm}$ dimension), the average compressive strength was $35 \mathrm{MPa}$. In this study, maximum gravel size and the specific gravity were $12 \mathrm{~mm}$ and $2.6 \mathrm{~g} / \mathrm{cm}^{3}$, respectively. Moreover, the water absorption rate of the specimen was $1 \%$. The gravel grading curve was based on ASTM C33. The sand size was a combination of $0-3 \mathrm{~mm}$ and 3-6 mm. Its specific gravity was $2.65 \mathrm{~g} / \mathrm{cm}^{3}$, and the water absorption rate was $1.45 \%$. The sand grading curve was based on ASTM C33. Cement type II with a specific gravity of $3.15 \mathrm{~g} / \mathrm{cm}^{3}$ was used.

In order to reinforce the concrete and manufacture the $\mathrm{RC}$ beams, 10- $\mathrm{m}$ and 14-mm rebars were used. The 10- $\mathrm{mm}$ rebars were used for internal reinforcements, and 14-mm rebars were utilized for longitudinal reinforcements. The rebar layout is shown in Fig. 2. Rebar yielding strength was measured according to ISO 6982-1 as such three specimens with $75-\mathrm{cm}$ length were selected and used for uniaxial tension test.

The average yielding strength for 10 - and 14-mm rebars was 417 and $435 \mathrm{MPa}$, respectively. FRP strips, QUANTOM Wrap 200C, and epoxy resins, QUANTUM EPR 3001, were used for rehabilitation. According to the properties noted in the manufacturer's catalog, the tensile strength for this composite material is $4950 \mathrm{MPa}$. Tensile E-modulus is 240 $\mathrm{GPa}$, and the elongation ratio is $1.5 \%$. Density is $1.8 \mathrm{~g} / \mathrm{cm}^{3}$, areal weight is $200 \mathrm{~g} / \mathrm{m}^{2}$, and the thickness is $0.111 \mathrm{~mm}$.

\subsection{Rehabilitation steps}

The eight specimens were manufactured and rehabilitated with FRP strips with $10-\mathrm{mm}$ overlaps. Rehabilitation with FRP was performed based on the following steps (Fig. 3):

1. First, a brush was used to smoothen the concrete surface of the beam. Then, the beam was washed to remove the dust and prepare it for FRP installation [29]. 
Table 1 Details of beam specimens

\begin{tabular}{|c|c|c|c|c|}
\hline No. & Specimen & Specimen Details & Description & $\begin{array}{c}\text { Purpose of } \\
\text { manufacturing }\end{array}$ \\
\hline 1 & $\begin{array}{c}\text { SCB } \\
\text { (Strengthened } \\
\text { Control Beam) }\end{array}$ & 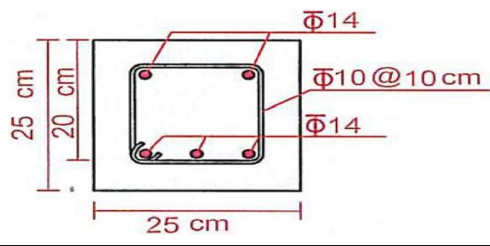 & $\begin{array}{l}\text { Control reinforced concrete } \\
\text { beam }\end{array}$ & $\begin{array}{l}\text { Comparing with } \\
\text { other specimens }\end{array}$ \\
\hline 2 & $\begin{array}{c}\text { SBDRS } \\
\text { (Strengthened Beam } \\
\text { Damaged Rebars } \\
\text { Symmetric) }\end{array}$ & Rebar Corrosion & $\begin{array}{l}\text { Reinforced concrete beam with } \\
\text { symmetric rebar corrosion }\end{array}$ & $\begin{array}{l}\text { Comparing with } \\
\text { SBDRA specimen }\end{array}$ \\
\hline 3 & $\begin{array}{l}\text { SBDRA } \\
\text { (Strengthened Beam } \\
\text { Damaged Rebars } \\
\text { Asymmetric) }\end{array}$ & Rebar Corrosion & $\begin{array}{l}\text { Reinforced concrete beam with } \\
\text { one-sided rebar corrosion }\end{array}$ & $\begin{array}{l}\text { Comparing with } \\
\text { SBDRS specimen }\end{array}$ \\
\hline 4 & $\begin{array}{c}\text { SBDCM15*3 } \\
\text { (Strengthened Beam } \\
\text { Damaged Concrete } \\
\text { Mid } 15 * 3 \text { ) }\end{array}$ & 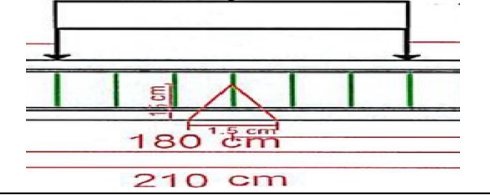 & $\begin{array}{l}\text { Reinforced concrete beam with } \\
\text { rebar corrosion in the middle } \\
\qquad(3 * 15 \mathrm{~cm})\end{array}$ & $\begin{array}{l}\text { Comparing with } \\
\text { SBDCO15*3 } \\
\text { specimen }\end{array}$ \\
\hline 5 & $\begin{array}{c}\text { SBDCO15*3 } \\
\text { (Strengthened Beam } \\
\text { Damaged Concrete } \\
\text { One-third } 15 * 3 \text { ) }\end{array}$ & \begin{tabular}{|l|l|l|l|l|}
\multicolumn{4}{|c|}{$60 \mathrm{~cm}$} \\
$\Delta$ & & & & \\
\end{tabular} & $\begin{array}{l}\text { Reinforced concrete beam with } \\
\text { rebar corrosion in } 1 / 3 \text { length } \\
\qquad(3 * 15 \mathrm{~cm})\end{array}$ & $\begin{array}{l}\text { Comparing with } \\
\text { SBDCM15*3 } \\
\text { specimen }\end{array}$ \\
\hline 6 & $\begin{array}{c}\text { SBDCM10*3 } \\
\text { (Strengthened Beam } \\
\text { Damaged Concrete } \\
\text { Mid } 10 * 3 \text { ) }\end{array}$ & 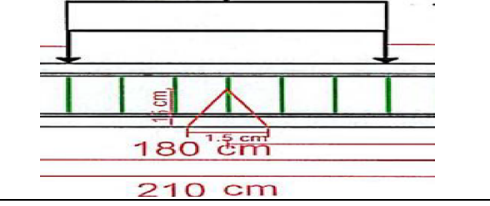 & $\begin{array}{l}\text { Reinforced concrete beam with } \\
\text { rebar corrosion in the middle } \\
\qquad(3 * 10 \mathrm{~cm})\end{array}$ & $\begin{array}{l}\text { Comparing with } \\
\text { SBDCM15*3 } \\
\text { specimen }\end{array}$ \\
\hline 7 & $\begin{array}{c}\text { SBDCM15*1 } \\
\text { (Strengthened Beam } \\
\text { Damaged Concrete } \\
\text { Mid-15*1) }\end{array}$ & $\frac{\frac{\mathrm{E}}{180 \mathrm{~cm}}}{210 \mathrm{~cm}}$ & $\begin{array}{l}\text { Reinforced concrete beam with } \\
\text { rebar corrosion in the middle } \\
\qquad(1 * 15 \mathrm{~cm})\end{array}$ & $\begin{array}{l}\text { Comparing with } \\
\text { SBDCM15*3 } \\
\text { specimen }\end{array}$ \\
\hline 8 & $\begin{array}{l}\text { SBDCM15*1+10*.5 } \\
\text { (Strengthened } \\
\text { Beam Damaged } \\
\text { Concrete } \\
\text { M15*1+O10*.5 } \\
\end{array}$ & 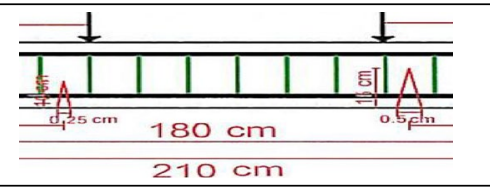 & $\begin{array}{l}\text { Reinforced concrete beam with } \\
\text { rebar corrosion in middle }(1 * 15 \\
\mathrm{cm}) \text { and } 1 / 3 \text { length }(0.5 * 10)\end{array}$ & $\begin{array}{l}\text { Comparing with } \\
\text { SBDCM15*3 } \\
\text { And } \\
\text { SBDCM10*3 } \\
\text { specimen } \\
\end{array}$ \\
\hline
\end{tabular}




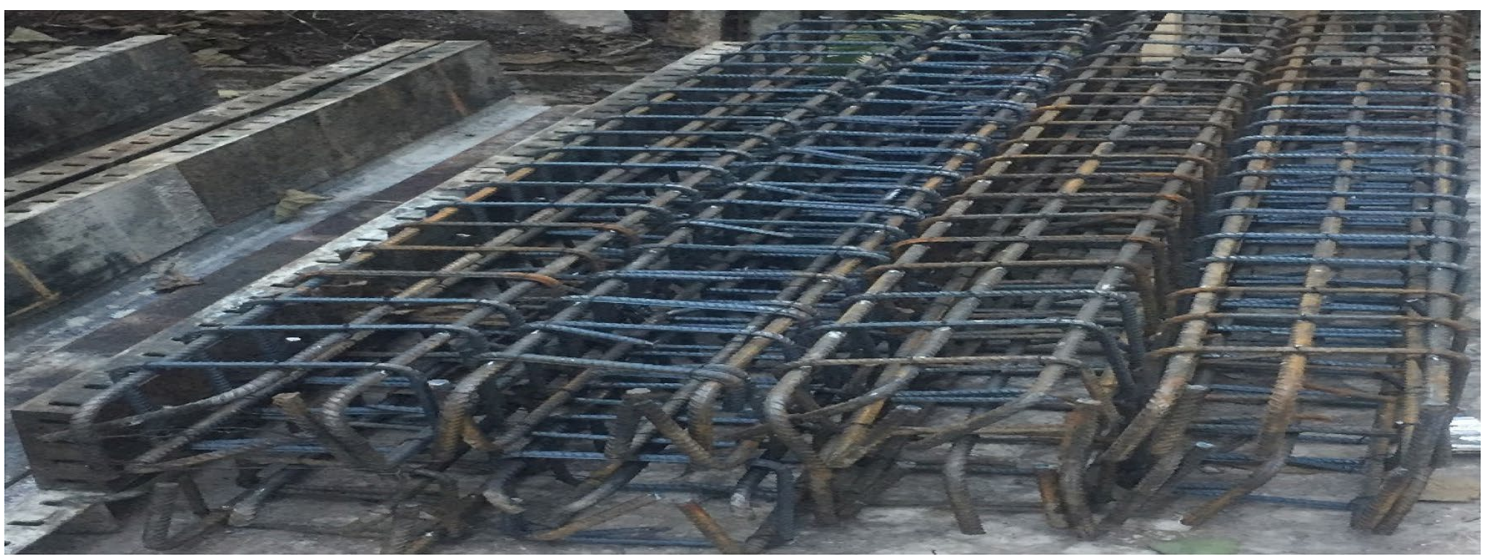

Fig. 2 Corrosion method of rebar
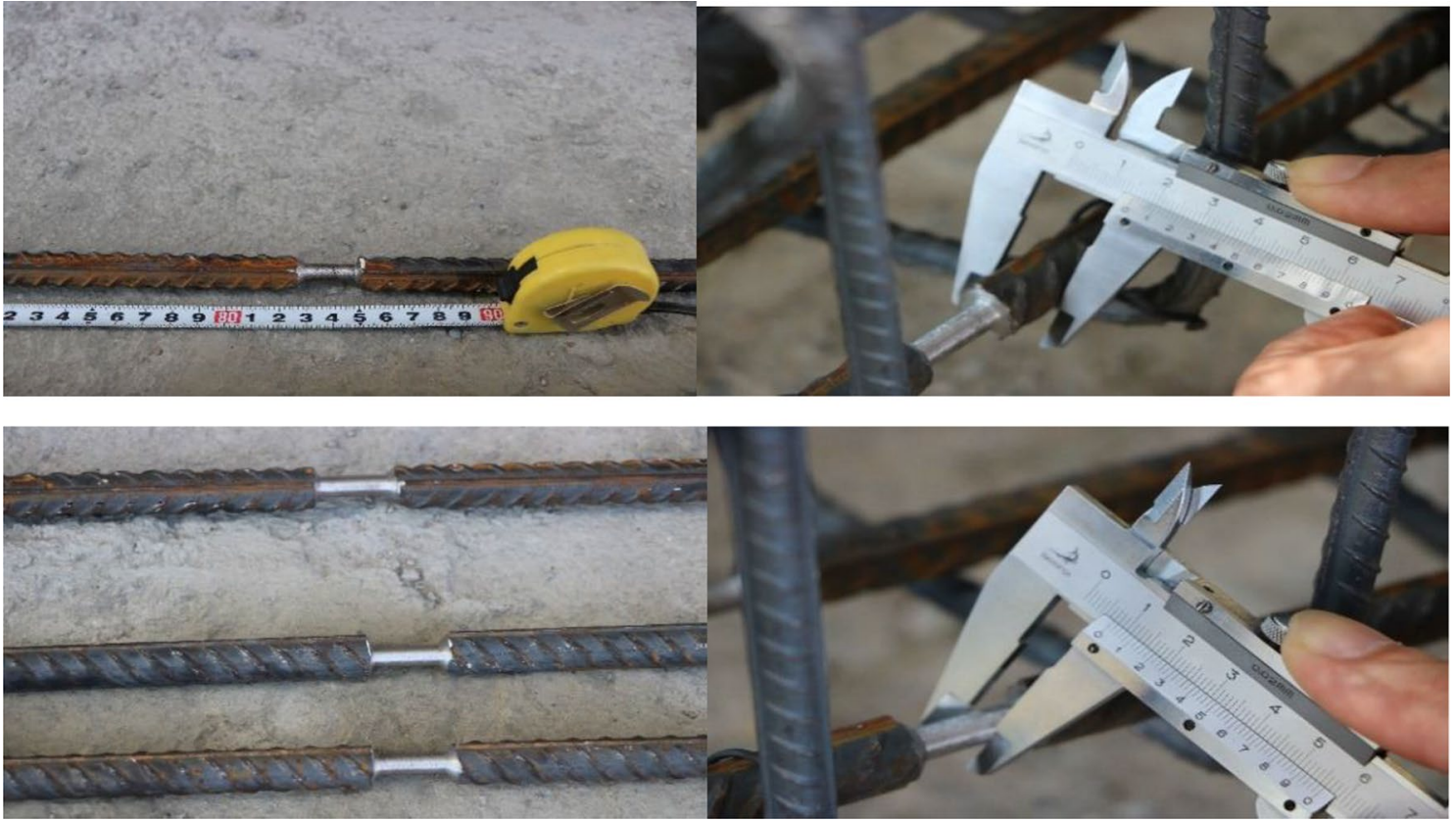

Fig. 3 Longitudinal and transverse rebars and their layout

2. FRP strips with 8-mm width and 110-mm length were provided.

3. A combination of adhesive and resin, with a ratio of 1 to 3 , was prepared. This proportion would result in maximum strength.

4. Seven FRP stripes were installed on the RC beam, $72 \mathrm{~h}$ before testing the specimens.

\subsection{Test procedure}

Figure 4 shows the details of the loading on the beams. In $\mathrm{RC}$ beams, compressive jacks applied the force in $60-\mathrm{cm}$ spaces using a plate. The space between the support and the beam edge was $15 \mathrm{~cm}$, and the 4-point loading was used for testing. In each test, three LVDTs were used to measure the beam deflection in the damage process. One LVDT was placed in the middle point, and the other two were placed in a $20-\mathrm{cm}$ space at either side of the middle span.

Electric strain gauges were installed on each beam to control the response of bending rebars (Fig. 4). Loading was done using a hydraulic jack with $1000-k N$ capacity.

It is placed in the middle of the beam opening to measure the vertical displacement of the specimens and also at two points of one-third of the LVDT opening. It is connected to the data logger via telephone wire, and all 


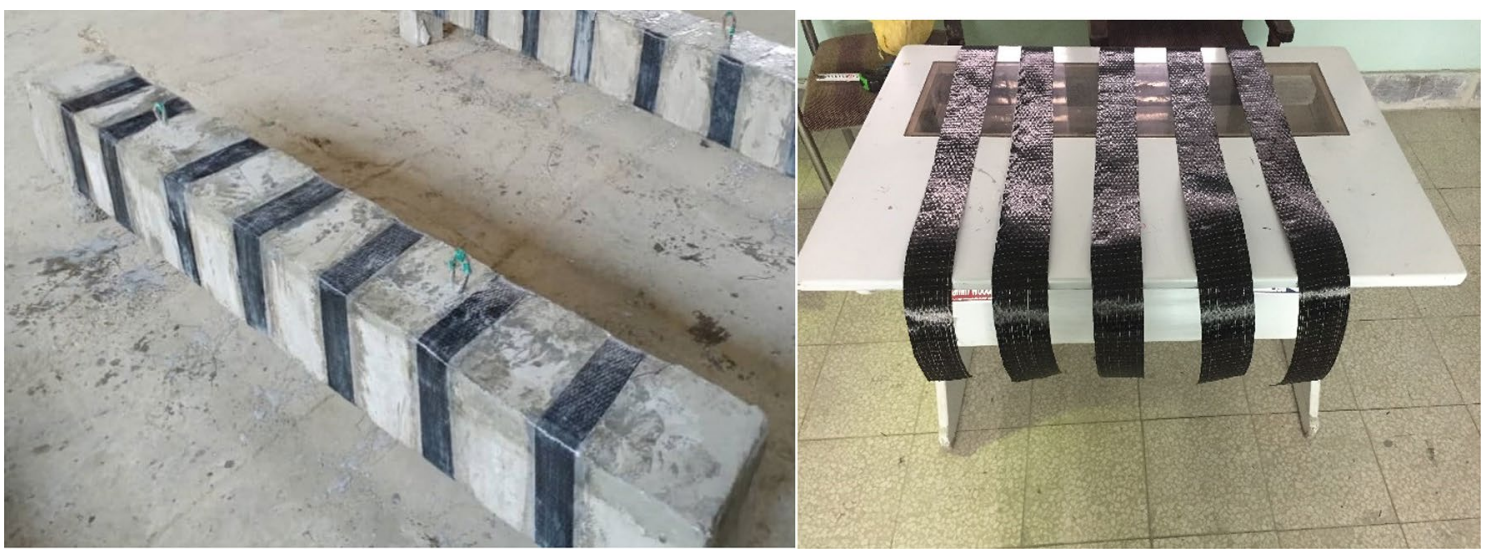

Fig. 4 FRP strips preparation

Table 2 Test results for RC beam specimens

\begin{tabular}{lllll}
\hline Specimen & $\begin{array}{l}\text { Load corresponding to } \\
\text { the first crack }(\mathrm{kN})\end{array}$ & $\begin{array}{l}\text { Maximum deflection in the mid- } \\
\text { dle point of the beam }(\mathrm{mm})\end{array}$ & $\begin{array}{l}\text { Test ultimate } \\
\text { load }(\mathrm{kN})\end{array}$ & $\begin{array}{l}\text { The ratio of test ultimate SBC } \\
\text { load to ultimate load of the } \\
\text { specimen }\end{array}$ \\
\hline SBC & 26 & 75 & 188 & 1 \\
SBDCM (10-0.5)(15-1) & 41 & 61 & 159 & 0.85 \\
SBDCM (10-3) & 26 & 82 & 159 & 0.85 \\
SBDCM (15-1) & 29 & 75 & 171 & 0.91 \\
SBDCM (15-3) & 40 & 71 & 152 & 0.81 \\
SBDCO (15-3) & 38 & 80 & 174 & 0.93 \\
SBDRA & 17 & 70 & 52 & 0.28 \\
SBDRS & 27 & 80 & 50 & 0.26 \\
\hline
\end{tabular}

information is stored in it every second in all experiments. The LVDT used shows a maximum rise of $20 \mathrm{~cm}$. The load cell is used to create a compressive force and is applied by the plate as a four-point force. Its capacity is 50 tons, which is gradually applied to the desired point.

\section{Test results}

Before applying any loading to the beam, a large number of micro-cracks appeared in the concrete, in the space between coarse aggregates and mortar. Accordingly, the spread of these cracks during loading leads to a nonlinear response of concrete under low stress and an increase in concrete volume close to the damage point. These microcracks might be the result of segregation, bleeding, or thermal expansion in mortar during the loading process. This is caused by the difference between the stiffness in aggregates and mortars. The concrete tensile strength is much lower than its compressive strength, and the tension area is prone to cracking when it reaches the tensile strength. In RC beams, the cracks are inevitable if the load increases; hence, in the preliminary stages of loading, crack or cracks appear on critical points, where the maximum bending moment is present. With an increase in load size, other areas reaching the concrete tensile strength start to crack. Table 2 shows the results for the load of the first cracking, bearing capacity, and the middle-point deflection in the maximum loading according to test results. It can be noticed that the rebar damage has the greatest impact on the strength of RC beams. In the beam SBDRS, with rebar damage in two sides, the bearing capacity, in comparison with the control specimen, decreased by $74 \%$.

The following diagram shows the force-displacement of the control beam, specimens with damage in the middle point, and specimens with different concrete damages. According to Fig. 5, the beam with two damages has the least deflection and bearing capacity among all the beam specimens. When comparing the beams with damage in the same location, it was revealed that the beam with less damage width has the highest bearing capacity.

In Fig. 6, the control concrete beam is compared with specimens having two types of rebar damage. It can be noticed that the exerted force and absorbed energy are

\section{SN Applied Sciences}




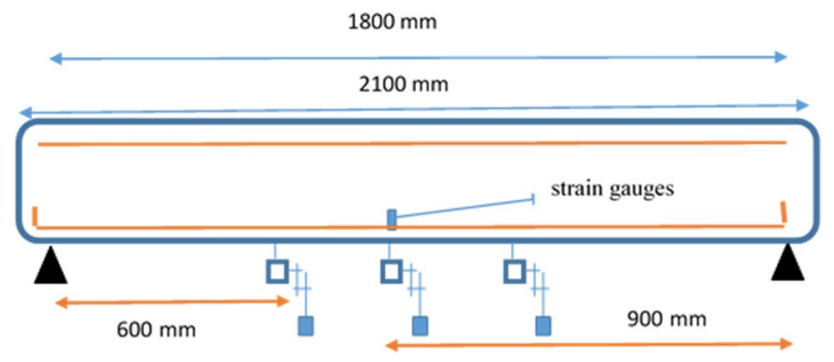

Fig. 5 Schematic view of the beam layout, loading and measurement instruments

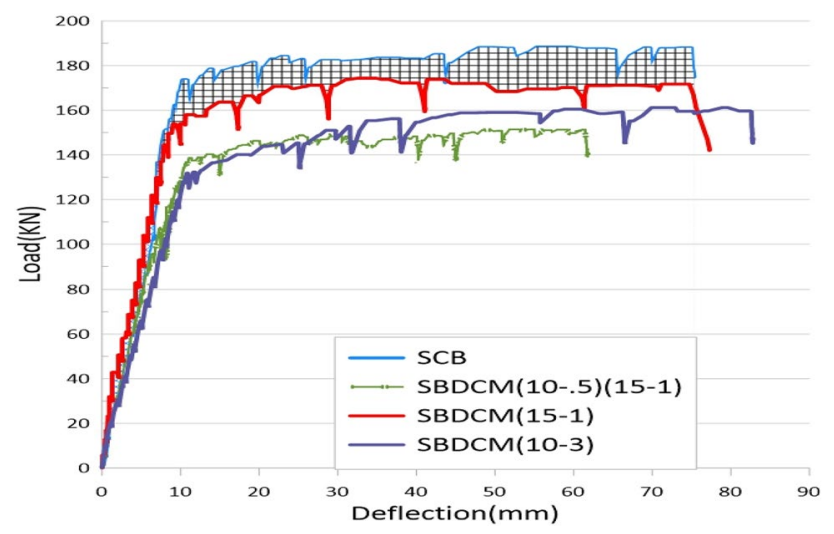

Fig. 6 Load-displacement diagrams of specimens having degradation in the middle

significantly different in these specimens. The specimen with symmetric rebar damage has lower energy absorption, and its bearing capacity is decreased by $7 \%$. As can be seen, despite the weakness and crack in the concrete, the load-carrying capacity of the control and damaged beams is similar due to the use of CFRP. In another research, the use of reinforcement has increased the load-carrying capacity and compensated for the defect in concrete.

The main reason for using this method for reinforcement and the intentional creation of damage in the rebar and the concrete is that concrete cracks and rebar corrosion are very common in the construction industry. Furthermore, this concrete reinforcement method is simple, practical, and readily available. Accordingly, we have employed this method for reinforcement analysis in order to prevent load-carrying weakness in beams [30].

In Fig. 7, the control specimen is compared with the two other specimens having similar damages. In one specimen, damage is located in the middle, and damage in the other ones is located in the $1 / 3$ point of the beam span. It can be mentioned that the latter endured more force and displacement and has more energy absorption rate. The control specimen has identical reinforcement and

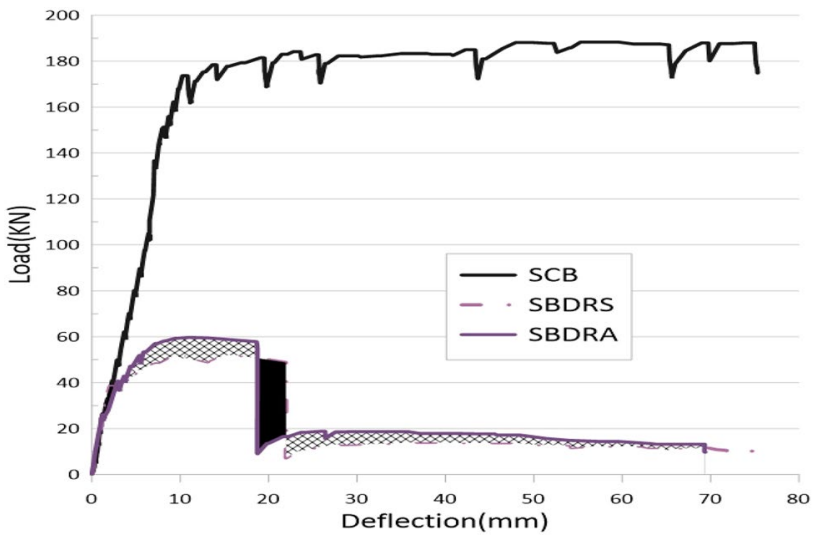

Fig. 7 Load-displacement diagrams of specimens having corroded rebars

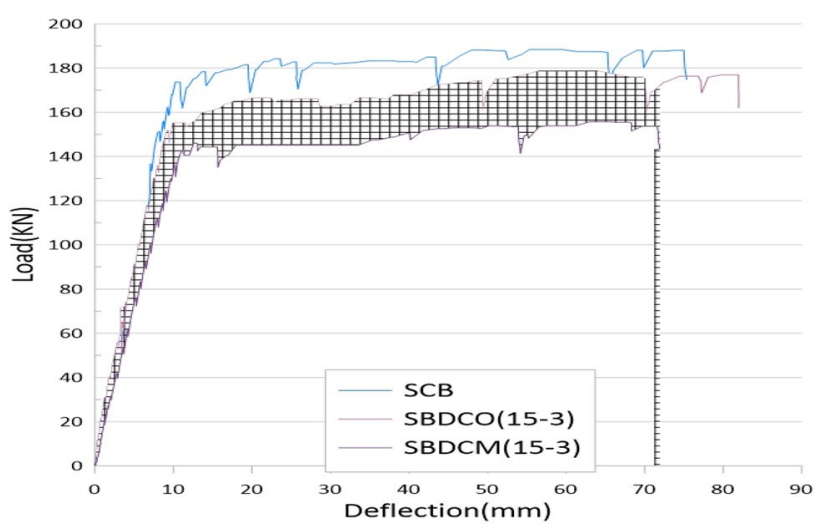

Fig. 8 Load-displacement diagrams in specimens having the same damage

thus similar displacement. Its bearing capacity, however, increased $14 \%$ and compared with the specimen with middle span damage.

In Fig. 8, the control beam is compared with the specimens with central damage and with different widths and heights. It can be observed that the damage width is much more effective than the other variables. The specimens with greater damage width and lower height show more displacement under the less force.

In Fig. 9, the blank sample was compared with centerdamaged samples with different widths and heights. As shown in the figure, the effect of damage is higher in the width than in the height. However, samples containing damage with larger width and smaller height exhibit smaller displacement for a smaller force.

According to Fig. 10, damage in the rebar has a great impact on reducing the bearing capacity. Also, this sample has less bearing capacity compared to other samples that have damage in concrete. The SCB sample has the highest 


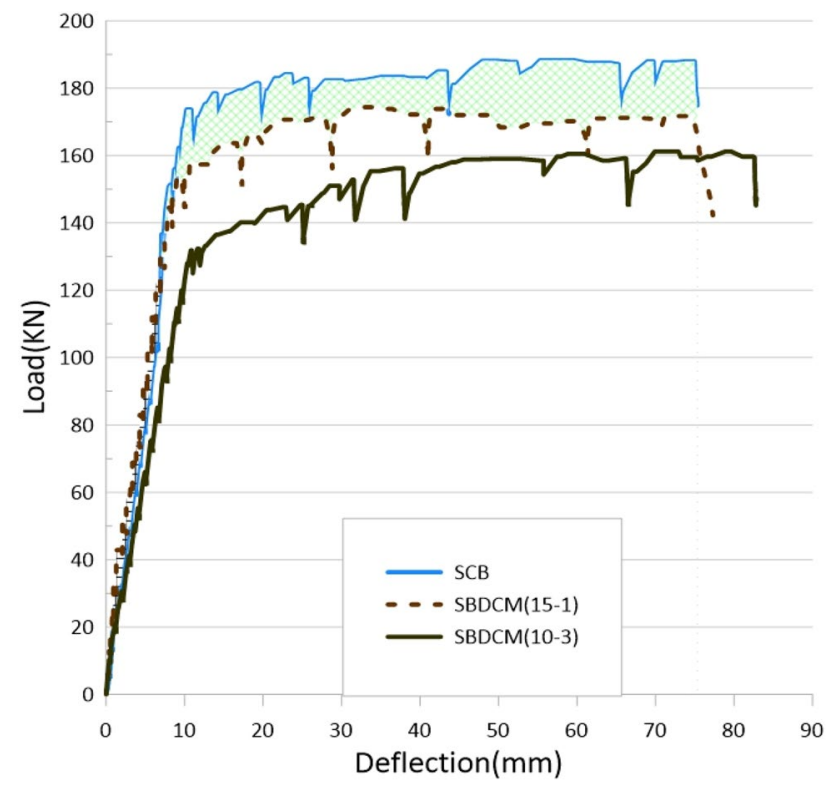

Fig. 9 Load-deflection of specimens with different damage widths and heights

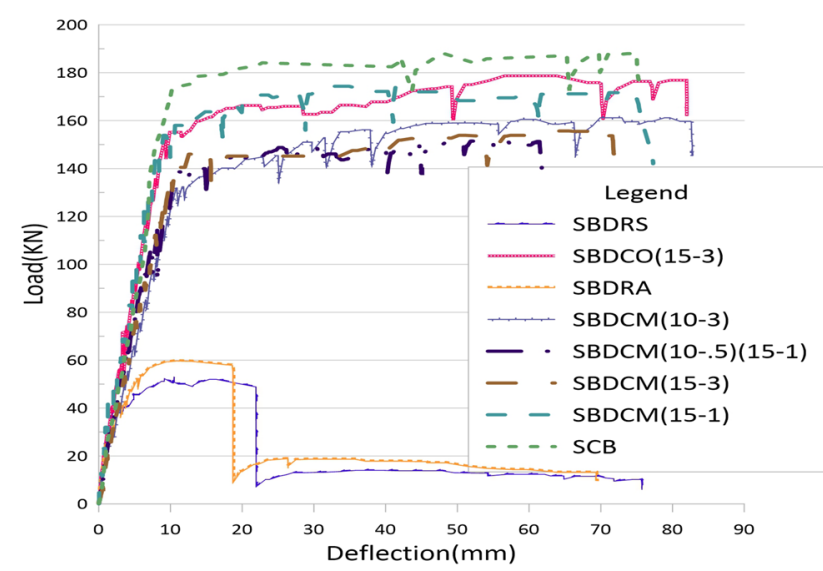

Fig. 10 Comparison of load-displacement for all specimens

load capacity and then damage in one-third of the opening as expected. However, despite the use of CFRP, the bearing capacity of all samples is very close to each other and this can be considered as a very important point in strengthening the beams. Notably, the bearing capacity of all samples is very close to each other despite the use of CFRP. This can be considered a very important point in strengthening the beams.

\section{State of failure}

Figure 11 shows the post-failure states for RC beams. As can be seen, the specimens have bending cracks, and the cracks are centered at the vertical direction. These cracks
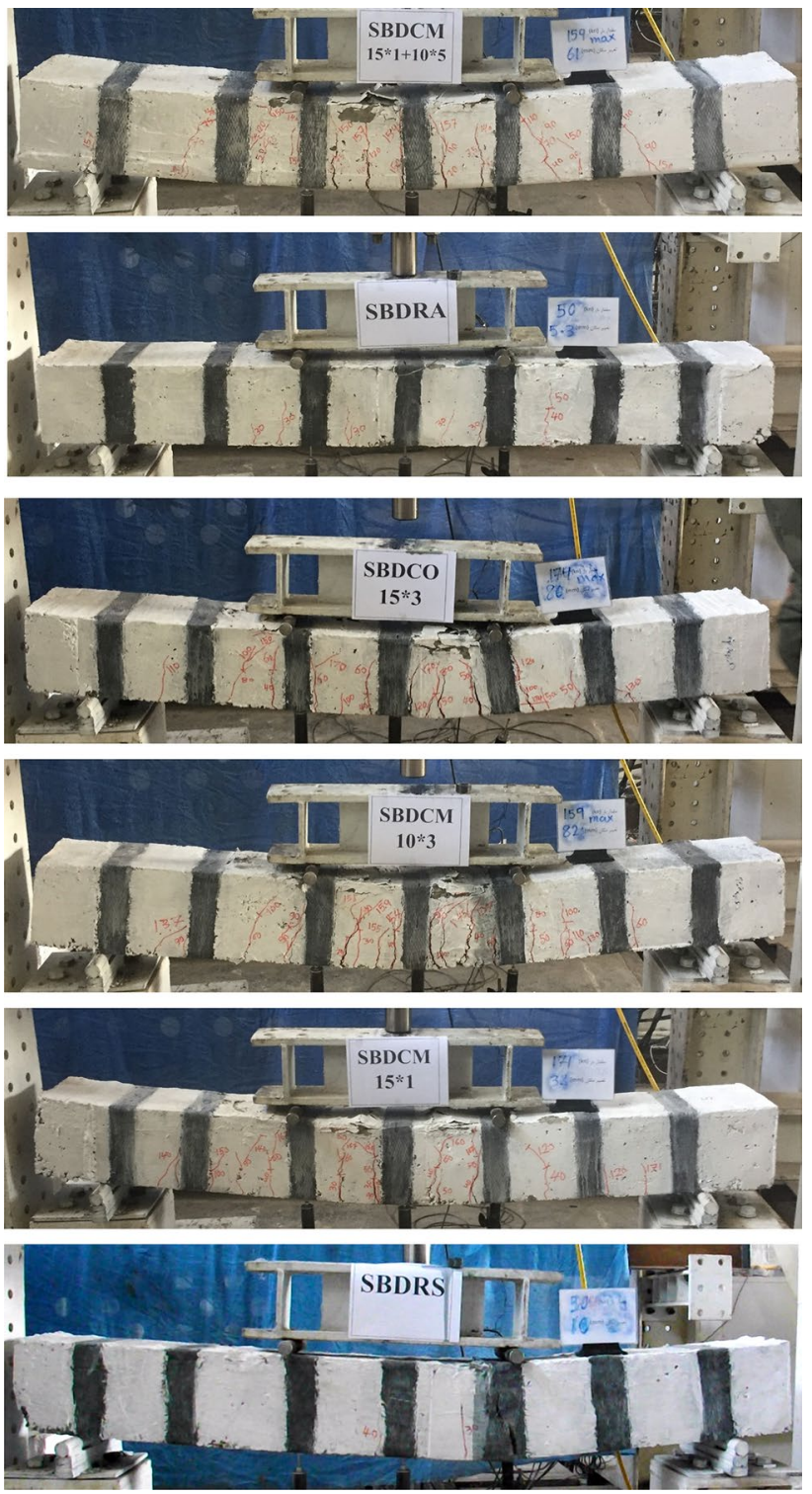

Fig. 11 Crack spread pattern of specimens corresponding to the fracture moment

start from the bottom of the beam and spread upward. In the control specimen, the cracks are fully distributed. Getting away from the beam center would result in an increase in the crack angles. If the load increases, cracks will develop. Eventually, when the transverse rebars yield, the beam will reach its maximum loading capacity. In SBDCM $15^{*} 1$ specimen, since the damage is located in the middle, the cracks are vertical and placed in the middle. With getting away from the middle point, cracks incline, and the crack concentration is in the vicinity of the damage region (Fig. 11) [31]. In the specimens with rebar damage, specimen fractures from the rebar damage region occur quickly. Moreover, in the SBDRS specimen, since FRP is used in the rebar damage region, composite fractures occurred (Fig. 12). 


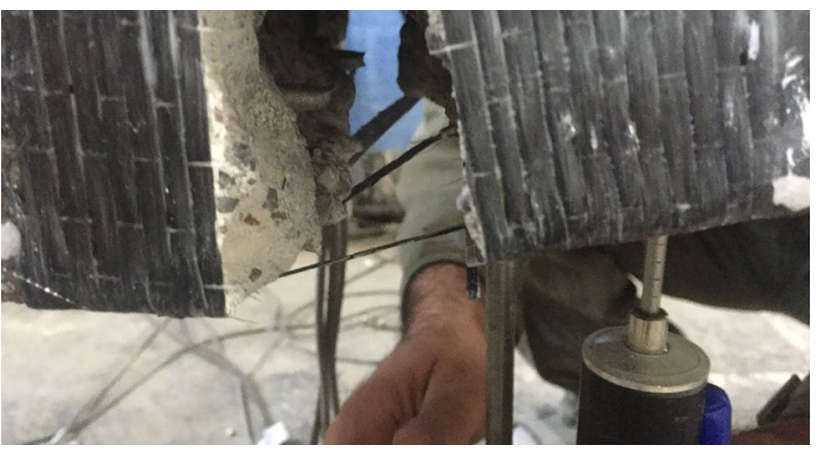

Fig. 12 Rebar failure pattern in SBDRS

Numerous studies have been conducted on the behavior of reinforced concrete Strengthened with FRP. In most cases, due to the outer connection of the reinforcement (FRP), the system always suffers from fracture. Numerous solutions have been proposed to resolve this issue. Here, no fracture of the FRP strips was witnessed since correct connection and coating were observed [32].

In other specimens with some sort of damage, concrete and rebar reached their maximum bearing capacity, and the beam reached the ultimate damage.

\section{Strains in longitudinal rebars}

Figure 11 shows the strains observed in the longitudinal rebars, which are measured by strain gauges installed on the point where the load was applied. The diagrams represent that in the initial phase of loading, the strain is minimal, and the curves are almost similar. However, with an increase in loading, each curve shows its specific trend, and different longitudinal rebars experience different strains. These curves demonstrate that shear reinforcement affects the strains in the longitudinal rebars.

As shown in Figs. 13 and 14, under similar loading conditions, the specimen with greater heights experience more strain in comparison with the other similar specimens. The comparison of the specimens with the control specimen indicated that the control beam demonstrates fewer rebar strains since the concrete can help the rebar in this regard.

In Fig. 15, the damaged specimens are compared with the control specimen. As presented, the damaged beam experiences less strain under similar loading conditions. It might be attributed to the role of the rebar. In addition to the existing failures, the main load is also applied to the rebar; therefore, it reaches the control specimen strain at a higher load level. The diagram path does not change much, and there is no obvious difference with the samples containing concrete damage. The reason is that comparing

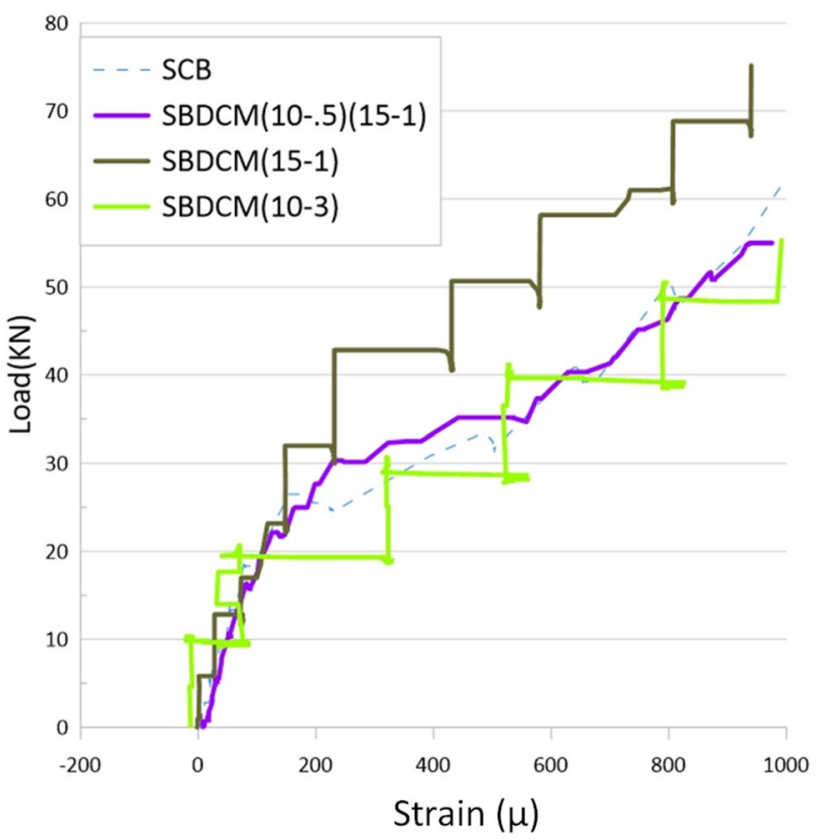

Fig. 13 Load-strain curves for three specimens compared to those of the control beam

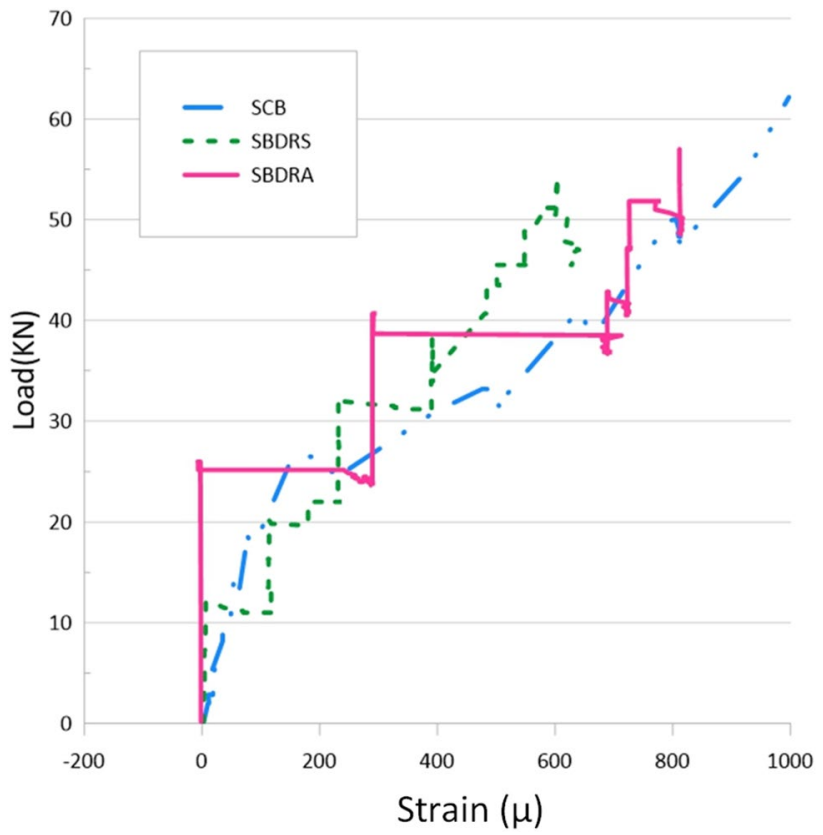

Fig. 14 Load-strain curves for two specimens compared to those of the control beam

the damaged samples with the control sample shows the same shear reinforcement is used in all samples (Figs. 13, $14,15,16)$. In particular, Fig. 16 shows that the SBDCM (153) \& SBDCO (15-3) samples overlap with the SCB sample. 


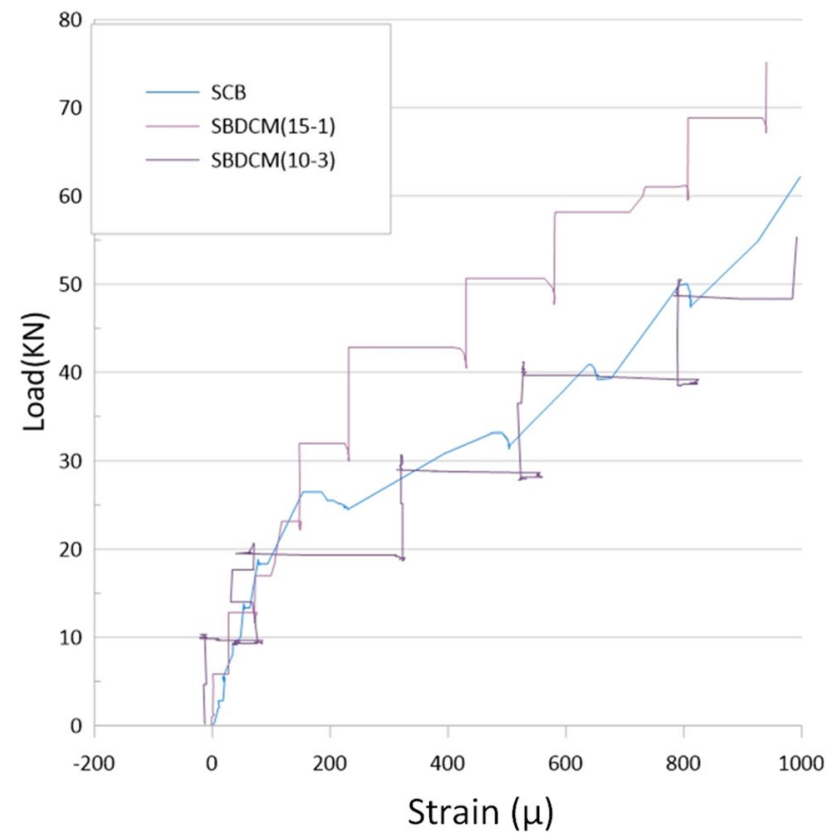

Fig. 15 Load-strain curves for two specimens compared to those of the control beam

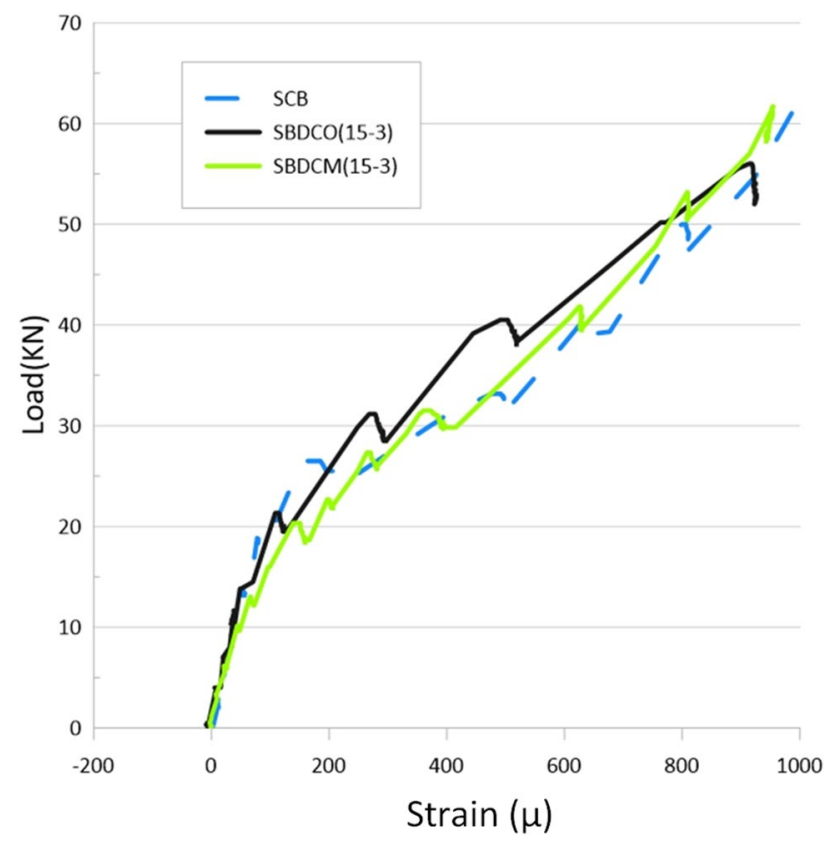

Fig. 16 Load-strain curves for two specimens compared to those of the control beam

\section{Energy}

The area under the force-displacement curve is the energy absorbed by the structure. This energy can be examined during earthquakes and higher structure performances. Table 3 shows the area under the force-displacement curve for eight manufactured beams. The smallest and largest values are for SBDRS and SBDCO specimens, respectively (15-3). The two concrete beams with rebar damage, in comparison with the control beam, only managed to absorb as much as $13 \%$ of the existing energy. For SBDCM (10-3) and SBDCM (15-1) specimens, the values were more than $90 \%$.

\section{Conclusion}

In this study, eight full-scale RC beams were manufactured and tested in order to reveal the response of the beams reinforced with FRP sheets. The effects of parameters such as rebar damages (decreasing diameter in the middle section and the $1 / 3$ of the total length) and concrete damages (cracks with different widths and heights located in the middle or $1 / 3$ of the total length) were examined. The following conclusions were made:

- In all the manufactured specimens, bending failure occurs, and cracks are vertical in the middle and inclined in the sides. According to the location of the concrete failure in the beam, the crack concentration is higher in the concerned areas. In specimens with rebar damages, the beam is not extensively cracked, and cracking is limited to the location of the damage.

- Bearing capacity of the control beam with no particular damage is greater than all the other specimens'. The least bearing capacity is for the specimens with rebar damages. The least beam deflection is for the specimens with two damages. The most deflection is for specimens with rebar damages. This might be related to the specimen fracture.

- In all the specimens, a fracture occurs out of the FRP reinforcement region. It demonstrates the stability of the reinforced section. However, the FRP sheet located in the middle was fractured during the final loading.

- In all the beams, except the second beam with rebar damages, high ductility, and energy absorption rates were observed. Although these rates are lower compared to that of the control specimen, they could be completely acceptable and approved with respect to the damages. It can be concluded that the use of FRP and limited damage in concrete would result in a slight decrease in the bearing capacity, even though the energy absorption rate is satisfactory.

- The strains in the longitudinal rebars, located under the loading area, demonstrate that greater strain is 
Table 3 The area under the curve for concrete specimens

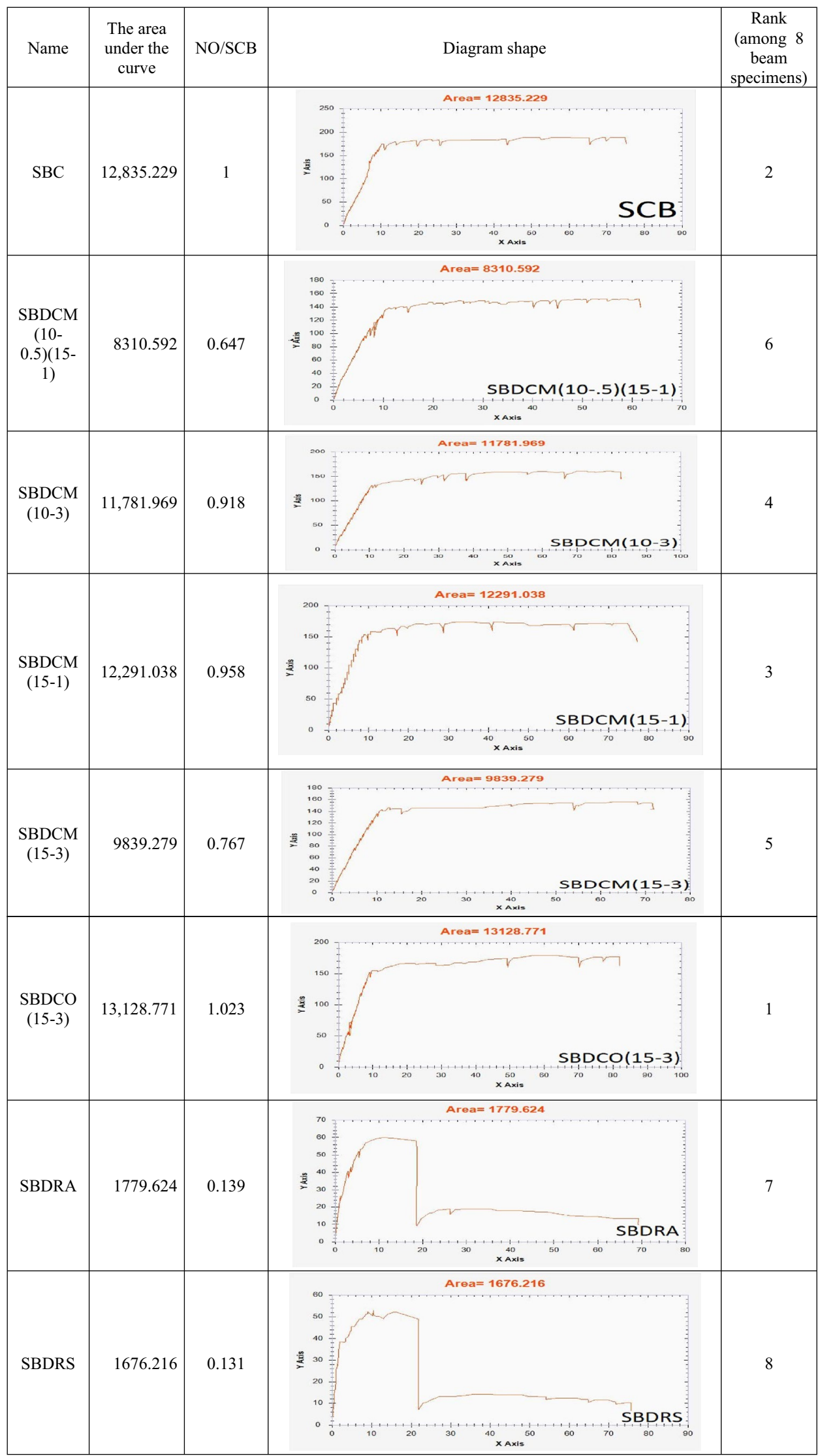


observed under the same loading conditions in concrete damages with larger widths. In addition, specimens with rebar damages sustain much less strain under the same loading conditions.

Funding This research received no external funding.

Data availability The raw/processed data required to reproduce these findings cannot be shared at this time as the data also form part of an ongoing study.

\section{Declarations}

Conflict of interest The authors declare no conflict of interest.

Ethical approval This article does not contain any studies with human participants performed by any of the authors.

Open Access This article is licensed under a Creative Commons Attribution 4.0 International License, which permits use, sharing, adaptation, distribution and reproduction in any medium or format, as long as you give appropriate credit to the original author(s) and the source, provide a link to the Creative Commons licence, and indicate if changes were made. The images or other third party material in this article are included in the article's Creative Commons licence, unless indicated otherwise in a credit line to the material. If material is not included in the article's Creative Commons licence and your intended use is not permitted by statutory regulation or exceeds the permitted use, you will need to obtain permission directly from the copyright holder. To view a copy of this licence, visit http://creativecommons. org/licenses/by/4.0/.

\section{References}

1. Erki MA, Meier U (1999) Impact loading of concrete beams externally strengthened with CFRP laminates. J Compos Constr 3(3):117-124

2. Dong J, Wang Q, Guan Z (2013) Structural behaviour of RC beams with external flexural and flexural-shear strengthening by FRP sheets. Compos Part B Eng 44(1):604-612

3. Choi E, Utui N, Kim HS (2013) Experimental and analytical investigations on debonding of hybrid FRPs for flexural strengthening of RC beams. Compos Part B Eng 45(1):248-256

4. Tureyen AK, Frosch RJ (2002) Shear tests of FRP-reinforced concrete beams without stirrups. Struct J 99(4):427-434

5. Bonacci JF, Maalej M (2001) Behavioral trends of RC beams strengthened with externally bonded FRP. J Compos Constr 5(2):102-113

6. Täljsten B (2003) Strengthening concrete beams for shear with CFRP sheets. Constr Build Mater 17(1):15-26

7. Yao J, Teng JG, Lam L (2005) Experimental study on intermediate crack debonding in FRP-strengthened RC flexural members. Adv Struct Eng 8(4):365-396

8. Teng JG, Smith S-T, Yao J, Chen J-F (2003) Intermediate crackinduced debonding in RC beams and slabs. Constr Build Mater 17(6-7):447-462
9. Klamer EL, Hordijk DA, Hermes MCJ (2008) The influence of temperature on RC beams strengthened with externally bonded CFRP reinforcement. Heron 53(3):157-185

10. Chajes MJ, Finch WW, Thomson TA (1996) Bond and force transfer of composite-material plates bonded to concrete. Struct J 93(2):209-217

11. Oehlers DJ (2001) Development of design rules for retrofitting by adhesive bonding or bolting either FRP or steel plates to $\mathrm{RC}$ beams or slabs in bridges and buildings. Compos Part $A$ Appl Sci Manuf 32(9):1345-1355

12. Kotynia R, Cholostiakow $S$ (2015) New proposal for flexural strengthening of reinforced concrete beams using CFRP T-shaped profiles. Polymers (Basel) 7(11):2461-2477

13. Almusallam TH, Elsanadedy HM, Al-Salloum YA (2015) Effect of longitudinal steel ratio on behavior of RC beams strengthened with FRP composites: experimental and FE study. J Compos Constr 19(1):4014028

14. Jumaat $M Z$, Alam MA (2008) Behaviour of $U$ and $L$ shaped end anchored steel plate strengthened reinforced concrete beams. Eur J Sci Res 22(2):184-196

15. Haddad RH, Marji CS (2019) Composite strips with U-shaped CFRP wrap anchor systems for strengthening reinforced concrete beams. Int J Civ Eng 17(11):1799-1811

16. Yoshitake I, Yumikura K, Mimura Y, Kim Y-J (2011) Composite strips with various anchor systems for retrofitting concrete beams. Int J Concr Struct Mater 5(1):43-48

17. Shahriari S, Naderpour H (2020) Reliability assessment of shear-deficient reinforced concrete beams externally bonded by FRP sheets having different configurations. Structures 25:730-742

18. Naderpour H, Alavi SA (2017) A proposed model to estimate shear contribution of FRP in strengthened RC beams in terms of adaptive neuro-fuzzy inference system. Compos Struct 170:215-227

19. Ahmed E, Sobuz HR, Sutan NM (2011) Flexural performance of CFRP strengthened RC beams with different degrees of strengthening schemes. Int J Phys Sci 6(9):2229-2238

20. Moradi E, Naderpour H, Kheyroddin A (2020) An experimental approach for shear strengthening of RC beams using a proposed technique by embedded through-section FRP sheets. Compos Struct 238:111988

21. Nguyen-Xuan H, Thai CH, Nguyen-Thoi T (2013) Isogeometric finite element analysis of composite sandwich plates using a higher order shear deformation theory. Compos Part B Eng 55:558-574

22. Wu Y-F, Huang Y (2008) Hybrid bonding of FRP to reinforced concrete structures. J Compos Constr 12(3):266-273

23. Haji M, Naderpour H, Kheyroddin A (2019) Experimental study on influence of proposed FRP-strengthening techniques on RC circular short columns considering different types of damage index. Compos Struct 209:112-128

24. A. C. I. Committee and I. O. for Standardization (2008) Building code requirements for structural concrete $(\mathrm{ACl} 318-08)$ and commentary. A. C. I. Committee and I. O. for Standardization, Indianapolis

25. Haddad RH, Shannag MJ, Hamad RJ (2007) Repair of heat-damaged reinforced concrete T-beams using FRC jackets. Mag Concr Res 59(3):223-231

26. Haddad RH, Shannag MJ, Moh'd A (2008) Repair of heat-damaged RC shallow beams using advanced composites. Mater Struct 41(2):287-299

27. Mhanna HH, Hawileh RA, Abdalla JA (2019) Shear strengthening of reinforced concrete beams using CFRP wraps. Procedia Struct Integr 17:214-221. https://doi.org/10.1016/j.prostr.2019.08.029

28. Naser MZ, Hawileh RA, Abdalla JA (2019) Fiber-reinforced polymer composites in strengthening reinforced concrete 
structures: a critical review. Eng Struct 198(November):109542. https://doi.org/10.1016/j.engstruct.2019.109542

29. Chen $C$ et al (2019) Mechanism of surface preparation on FRPConcrete bond performance: a quantitative study. Compos Part B Eng 163:193-206

30. Leung CKY, Chen Z, Lee S, Ng M, Xu M, Tang J (2007) Effect of size on the failure of geometrically similar concrete beams strengthened in shear with FRP strips. J Compos Constr 11(5):487-496

31. Zhou A, Qin R, Feo L, Penna R, Lau D (2017) Investigation on interfacial defect criticality of FRP-bonded concrete beams. Compos Part B Eng 113:80-90
32. Chen J-F, Teng JG (2003) Shear capacity of FRP-strengthened RC beams: FRP debonding. Constr Build Mater 17(1):27-41

Publisher's Note Springer Nature remains neutral with regard to jurisdictional claims in published maps and institutional affiliations. 